\title{
God en genot
}

\section{'n Teologies-etiese ondersoek na die gebruik van uti en frui by Augustinus}

\author{
J.H. van Wyk \\ Dept. Dogmatologie en Ekklesiologie \\ Potchefstroomse Universiteit vir $\mathrm{CHO}$ \\ POTCHEFSTROOM
}

\begin{abstract}
God and enjoyment: An investigation of uti and frui in Augustine's writings

It cannot be denied that the theology of Augustine in general and his ethics in particular have had an immense influence on theological scholarship, church practice and Christian life throughout the centuries. His use of especially the concepts uti and frui has had a great impact on Christian ethics. These concepts are generally understood in such a way that God must only be enjoyed (frui) for his own sake and everything else must be used (uti) (not enjoyed) for God's sake. The question, however, arises whether that is a correct interpretation of Augustine? Was he indeed more of a Neoplatonist and Stoicist than a Biblical theologian? In this article Augustine's use of these concepts as well as his influence on reformed ethics in this regard is investigated.
\end{abstract}

\section{Inleiding}

Augustinus, die kerkvader uit Noord-Afrika, troon soos 'n reus uit bo die Westerse teologie- en kerkgeskiedenis en sy invloed is tot in die Middeleeue, ja, tot in die Reformasie (dink aan Calvyn) sigbaar. Dit is daarom verbasend dat daar in Suid-Afrika relatief min aandag aan hom bestee is en dat daar oor sy etiek oor die algemeen, in vergelyking met die enorme aantal dogmatiese en filosofiese geskrifte oor hom, so min gepubliseer is - met die vroeë studie van Mausbach (1909, tweede uitgawe 1929) as welkome uitsondering. Wel is daar aan deelaspekte van Augustinus se etiek besondere aandag bestee, veral wat sy liefdesetiek betref. Augustinus word nie verniet naas doctor gratiae ook doctor caritatis (Brechtken, 1975) genoem nie. Een aspek wat voortdurend besinning opgeroep het, is, soos uit hierdie artikel sal blyk, Augustinus se hantering van die begrippe $u t i$ (gebruik) en frui (geniet).

Hierdie begrippe word veelvuldig deur Augustinus gebruik, sowel in sy vroeëre as in sy latere geskrifte. Terwyl later breedvoeriger daarop ingegaan word, word hier by wyse van inleiding na enkele opvallende voorbeelde verwys. Daar is 
dinge vir genieting/verlustiging (res quibus fruendum), sê Augustinus, en dinge vir gebnuik (quibus utendum) (kyk De doctrina Christiana 1.1.3; voortaan DDOC). Voorwerpe van genot maak ons gelukkig en voorwerpe van gebruik help ons op weg na dit wat gelukkig maak. Om iets te geniet, vervolg hy (DDOC 1.1.4), is om iets in liefde aan te hang ter wille van daardie ding self (propter se) en om te gebruik is om iets aan te wend ten einde dit te verkry wat jy begeer. Ons "geniet", sê Augustinus (DCD 11.25)1, dit wat ons op sigself verheug en ons "gebruik" daardie dinge wat ons met die oog op hoër doeleindes (ewige dinge) begeer. Tydelike dinge moet dus eerder "gebruik" as "geniet" word. Wie/wat is die "hoogste ding"? Antwoord: "God alleen moet bemin word; en hierdie hele wêreld, dit is alle sinlike dinge, moet verag word, terwyl hulle nogtans gebruik moet word soos hierdie lewe noodsaak" (De moribus ecclesiae catholicae 20.37; voortaan DME). Slegs God is objek van liefde ter wille van Homself (propter se); die mens se naaste is objek van liefde ter wille van iets (Iemand) anders (propter aliud). Alle menslike perversie bestaan daarin dat begeer word om te gebruik wat geniet moet word en om te geniet wat gebruik moet word, en die goeie orde bestaan daarin dat geniet word wat geniet moet word en gebruik word wat gebruik moet word (De diversis Quaestionibus 83.30; voortaan DD83).

Die kritiese vraag is al gestel of Augustinus nie hierdie onderskeiding - liefde as middel ( $u t i)$ en liefde as doel (frui) - uit die nie-Christelike filosofie oorgeneem het nie (Lorenz, 1952/53:60 wys op Varro; Duchrow, 1970:202 op Plotinus; Pfligersdorffer, 1971:215-224 op Cicero se Hortensius en Van Oort, 1991:143 ook nog op die Manicheisme). Lê hieraan nie 'n gnostiese wêreldbeskouing ten grondslag nie (Van Oort, 1991:145)? Kan die gesegde wat selfs vandag nog gewoonlik grappenderwys - gemaak word: "Doen dit maar, moet dit net nie geniet nie", nie dalk tot Augustinus herlei word nie?

Augustinus se beskouing van uti en frui plaas ons midde-in die etiek en roep nie net die vraagstelling van doel en middel na vore nie, maar ook van die Christen se gebruik en geniet van aardse goed, van vreemdeling-wees maar ook erfgenaamwees. Is Augustinus hierin 'n veilige wegwyser of is hy 'n valstrik?

Wie "Augustinus" is, is egter geen maklike saak nie. Daar is immers soveel Augustinusse as wat daar interpreteerders is. Vandaar dat daar eers kortliks aan enkele interpretasies aandag bestee word. Hieruit sal blyk dat dit geen eenvoudige saak is om Augustinus reg te verstaan nie.

$1 \quad \mathrm{DCD}=$ De civitate Dei. 


\section{Interpretasies}

Wie hom besig hou met die uti/frui-problematiek by Augustinus, loop hom vas in so 'n warnet van - soms briljante - interpretasies dat die vraag met reg gestel kan word of dit nog moontlik is om die "eintlike Augustinus" terug te vind. Die vraag dring hom ook na vore hoe Augustinus se eerste lesers sy afsonderlike geskrifte (kon) verstaan het, lesers wat nie die volledige Augustinus voor hulle gehad het soos ons hom vandag voor ons het nie, as daar tans soveel uiteenlopende menings selfs oor die "volle Augustinus" bestaan.

\section{- O'Donovan}

O'Donovan (1982:361-362) het 'n samevatting van die belangrikste navorsing tot op daardie datum gegee - en dan is sy tekening ook nog nie volledig nie. So verwys O'Donovan na studies van Mausbach (1909), Burnaby (1938), Hultgren (1939), Nygren (1954) en veral Holte (1962). Wat nie behandel word nie, is Scholtz (1929), Arendt (1929), Lorenz (1950-1951), Pfligersdorffer (1971) en Brechtken (1975) - afgesien nog van talle ander geskrifte waarin ons tema minder of net terloopse aandag ontvang. ${ }^{2}$

Die eerste, waarskynlik mees bekende onderskeiding, is dié waar naasteliefde gesien word as instrument om geluksaligheid (liefde vir/verlustiging in God) te bereik - genoem psigologiese of instrumentele benadering en deur my as die mediale benadering getipeer. In hierdie kategorie plaas O'Donovan dan vir Nygren (1954:512). Hiervolgens sou Augustinus in direkte teenspraak kom met die standpunt van Kant waarvolgens die naaste nooit as middel nie maar altyd as doel gebruik behoort te word.

Inderdaad het Nygren (1954:351-440) breedvoerig aandag aan Augustinus se liefdesbegrip bestee. Volgens Nygren weeg die eros-etiek by Augustinus die swaarste en is die liefde tot God 'n middel tot selfbevrediging, wat eintlik neerkom op 'n opheffing van (ware) liefde. Volgens Augustinus sou ons eintlik niks van die wêreld mag liefhê nie. Nygren se interpretasie van Augustinus het egter grondige kritiek van Brechtken (1975:188-194) en veral Canning (1983b:217-231; vgl. ook Grabowski, 1957:348) opgeroep.

'n Tweede standpunt wat O'Donovan noem en waartoe hy Mausbach se siening (II 1929:64 e.v., 223 e.v., 265 e.v.) reken, lê die klem op die ontologiese orde van die geskape werklikheid. Daar is 'n bepaalde orde in die werklikheid (bv.

2 Vergelyk slegs die volgende: Gilson, 1930:289-301; Grabowski, 1957:363-367; Marrou, 1981:290-291; Van Oort, 1991:142-145; Clark, 1994:44-45; Van der Zwaag, 1993:165-170; De Kruijf, 1994a:64-66; 1994b; Horn, 1995:47-49. In die bocke van Brown (1969) en TeSelle (1970) ontvang die vraagstuk geen of weinig aandag (vgl. TeSelle, 1970:66-67, 130). Hoewel die bock van Brown as biografie waarskynlik onoortreflik is, is daar tog 'n gebrek aan teologiese koloriet in sy uiteensetting; hiervoor vergood dic bock van TeSelle. 
dinge, mense, God) en die liefde moet daarmee korreleer - deur my genoem die finale benadering. Hiertussen, so oordeel O'Donovan, lê 'n bemiddelende standpunt wat bogenoemde twee benaderings probeer saamdink - soos byvoorbeeld by Hultgren (1939) en Burnaby (1938:106) te vind is. O'Donovan (1982:363) dink self sterk in hierdie rigting. 'n Vierde standpunt wat O'Donovan (1982:363-373) oorweeg maar afwys, 'n standpunt wat weer deur Canning (1983b:168) byna aksiomaties aanvaar word, is dié van die Sweed Holte (1962), wat aangevoer het dat dinge-vir-gebruik en dinge-vir-genot/verlustiging in die denke van Augustinus verband hou met (en georden word deur) die twee vlakke van die menslike redelike siel; elke deel van die siel het 'n spesiale objek van liefde, sodat die interne ordening van die siel in die liefdesdaad met die buitewêreld korreleer.

Aan drie meer resente standpunte moet ietwat meer aandag gegee word, naamlik dié van Brechtken (1975), O'Donovan (1982) en Canning (1983b). Klaarblyklik het Canning nie van O'Donovan kon kennis neem nie. Die interessante is dat Canning (1983a:37; 1983b:203, 210-216, 220) die interpretasie van Brechtken skerp afwys en sterk aansluiting vind by Holte, wat weer deur O'Donovan (1983a:37) afgewys word.

\section{- Brechtken}

Brechtken voer aan dat volgens Augustinus die hoogste doel van die lewe is om geluk, die hoogste goed, dit is God, te vind. Binne hierdie raamwerk funksioneer die begrippe uti en frui. Die fruitio staan in die middelpunt van Augustinus se etiek en bepaal alles (Brechtken, 1975:3, 27, 30, 39, 53); sy etiek vertoon 'n appetitus-struktuur. Die vasstelling dat alle mense geluksaligheid soek, vorm die antropologies-ontologiese voorveronderstelling vir die algemene geldigheid van die moraal (1975:15). Gevolglik kan daar nie sprake wees van 'n teonome etiek nie maar wel van 'n "antropo-norme" moraal wat van die mens en sy geluk uitgaan (1975:16-17). Waar bly, vra Brechtken (1975:4, 131, 157), die volle en ware naasteliefde (agapé) soos die Nuwe Testament (1975:87-94) dit leer? Augustinus se sisteemdwang bring mee dat die medemens net $u t i$-objek kan wees (1975:98-99). Augustinus se bepaling van naasteliefde is "onlogisch, nicht durchdacht, ungeordnet und geradezu chaotisch" (Brechtken, 1975:133-134). Wat Brechtken (1975:57) veral pla, is dat Augustinus geen afsonderlike plek aan naasteliefde toeken nie (vgl. DCD 10.3): "Dies ist für uns das eigentliche Skandalon seiner Ethik". Die implikasie van Augustinus se standpunt is dat alle aardse dinge tot tweederangs gedegradeer moet word (1975:21); geluksaligheid is immers net in terme van die ewige denkbaar (1975:25). Daarby ontdek Brechtken (1975:99, 131-132) dat Augustinus ook nie konsekwent is in sy gebruik van die terme uti en frui nie; sy formulerings is soms duister (1975:84). Die groot probleem is dat Augustinus sy etiek uit die Griekse filosofie oorgeneem het en in sy Christelike teologie probeer integreer het (1975:85). Die frui deo het sy oorsprong in die filosofiese sedeleer (Lorenz, 1952/53:60 wys op Varro) 
(Brechtken, 1975:103). Augustinus se grootste fout is dat hy hom op die Heilige Skrif beroep om sy filosofiese idees te dek (1975:134-135).

In die verloop van hierdie artikel sal (meesal indirek) op die standpunt van Brechtken ingegaan word. Die vraag moet egter nou reeds gestel word of Brechtken hom nie self aan sisteemdwang skuldig gemaak het in sy interpretasie van Augustinus nie en die $u t i / f r u i$-vraag te min binne die konteks van Augustinus se totale denke behandel het. Het Brechtken nie te veel op De doctrina Christiana gesteun en Augustinus se ander werk nie genoegsaam verreken nie (Canning, 1983:215)? Het hy genoeg ruimte gelaat vir die korrigerende invloed van die Bybel op die denke van Augustinus? Dit val op dat hy aan homself die vraag stel of hy Augustinus nie onreg aangedoen het met 'n foutiewe interpretasie nie (Brechtken, 1975:106).

In sy belangrike artikel, wat handel oor die gebruik van usus en fruitio in De doctrina Christiana I, behandel O'Donovan (1982:361-397) die standpunt van Holte maar wys dit uiteindelik af, daarna gee hy aandag aan geskrifte van Augustinus vóór die publikasie van De doctrina Christiana I (396) en vervolgens aan laasgenoemde geskrif self, wat weer opgevolg is met 'n kort oorsig van latere geskrifte. O'Donnovan kom tot die konklusie dat die betekenis wat Augustinus aan die begrippe usus/fruitio gegee het, nie bepaal is deur ' $n$ hipotetiese Stoïsynse bron nie maar deur die konteks waarin elke begrip in Augustinus se vroeè geskrifte gebruik was. Volgens O'Donnovan dui die konteks vir die term usus op 'n hoofsaaklik instrumentele gebruik, wat versterk is deur die verband met die pelgrim-motief. Ook stel O'Donnovan dat Augustinus in De doctrina Christiana $I$ nog op twee gedagtes hink en begin hy tekens te toon om sy klassifikasie terug te trek; in sy latere werke vermy Augustinus die klassifikasie, neem dit eintlik terug en beskryf naasteliefde as 'n vorm van fruitio.

\section{- Canning}

Canning (1983b:165-231) wys in sy artikel eerstens op die algemene formulerings in verband met $u t i$ en frui, waarna hy spesifiek ingaan op De doctrina Christiana om af te sluit met 'n kritiese bespreking van Nygren. Opvallend is sy breë en omvattende aanpak van die onderwerp. Sy studie word egter in 'n groot mate bepaal deur Holte se standpunt dat die onderskeiding uti/frui na Cicero (Stoa) teruggevoer kan word, waar onderskei is tussen morele goed (deug) en die spesifieke objekte van keuse (Canning, 1983b:168). Augustinus deurbreek egter die Stoïsisme daarin dat die moreel-goeie vir hom nie gelee is in eie morele volmaaktheid nie maar in God en dat die gebruiksgoedere nie belangelose werklikhede is nie maar Voorsienigheidsgoedere. Canning (1983b:197; vgl. 185) vertolk die standpunt van Augustinus oor naasteliefde in DDOC (1.22.20) sodanig dat die naaste (as skepsel) nie as die einddoel van en maatstaf vir die lewe gemaak mag word nie. Nadat Augustinus met uti-naasteliefde begin het, het 
hy die term later tog te beperkend gevind (Canning, 1983b:198). "A careful reader of the first book of De doctrina Christiana will fail to discover any statement to the effect that the neighbour is to be used with a view to attaining our own individual happiness in the enjoyment of God" (Canning, 1983b:198). Vandaar ook Canning (1983b:210-216) se kritiek op Brechtken. Met sy formulering "geniet God" (of verlustig jou in God) eerder as die mens, wil Augustinus niks anders sê nie as dat die Godsliefde alles opeis - iets wat nie van die naasteliefde gesê kan word nie. Uiteindelik het Augustinus ingesien dat ten opsigte van die naaste nie eenvoudig uti of frui gebruik kan word nie en dat hierdie terme getransformeer moet word. Canning (1983b:218) stel ook aan Nygren die vraag of Augustinus se skema nie help om die relatiewe (die naaste) relatief te hou en die Absolute (God) absoluut nie. Daarby is Augustinus ook bedagsaam om mense (die self en die naaste) van ander objekte van uti te onderskei (1983b:220). Teenoor Brechtken en Nygren wys Canning (1983b:220) op die veelsydige subtiliteite by die gebruik van $u t i$ asook vir die kompleksiteit van frui; die uti/frui-onderskeiding mag nie simplisties verstaan word nie. Ook uit ander geskrifte van Augustinus, buite die uti/frui-spektrum om, blyk dat hy uitgesproke is oor selflose naasteliefde (Canning, 1983b:221, 229).

\section{Augustinus ${ }^{3}$}

Die weergawe sover mag die aandagtige leser vermoei het, maar dit was noodsaaklik ten einde begrip op te bou vir die problematiek waarvoor ons staan. Augustinus moet egter self aan die woord gestel word omdat maar alte goed besef word dat ons hier met geen eenvoudige saak te doen het nie en dat alle kennis medebepaal word deur voorveronderstellings, epistemologie en metodologie. Tog moet steeds daarna gestreef word om, ook in ons verstaan van Augustinus, so ver moontlik onbevooroordeeld en onbevange te luister na wat hy sê. By die weergawe van Augustinus se standpunt oor uti en frui sal 'n chronologiese orde gevolg word ten einde met sy teologiese ontwikkelingsgang rekening te hou. Hieruit sal ook blyk hoedat daar telkens nuwe nuanses en wendinge na vore tree in sy gebruik van die twee konsepte. 'n Hele aantal tekste sal gehanteer word, maar die aksent sal op twee hooftekste val, naamlik De doctrina Christiana I en De civitate Dei 19.

\subsection{Uitsprake tydens die Italiaanse periode (386-388)}

In een van sy vroegste "Christelike" geskrifte, geskryf kort na sy bekering (386) en sy doop (387) in Cassiciacum, buite Milaan, sê Augustinus in sy Soliloquia 1.22 (voortaan SO) dat hy niks anders (as Wysheid) bemin/liefhet, aangesien dit

3 By die bespreking van Augustinus word gebruik gemaak van dic Latynse tekste van die oorspronklike werk van Augustinus, asook van vertaalde werke - kyk 1.1 en 1.2 in die saamgestelde bibliografie. 
wat nie ter wille van homself bemin word nie, nié bemin word nie; uiteindelik bemin hy nou Wysheid slegs ter wille van haarself, terwyl ander dinge (soos lewe, gemak, vriende) ter wille van háár begeer word. Daarom dat dinge soos rykdom, eer en ' $n$ vrou nie deur hom begeer en aangehang kan word nie hoewel dit dinge is wat toelaatbaar is (SO 1.19). Dwarsdeur hierdie alleensprake is daar 'n skerp fokus op God (die Vader), terwyl die naam van Christus nêrens genoem word nie - iets wat eintlik vreemd voorkom by 'n pasbekeerde.

In sy De quantitate animae (voortaan DQA), geskryf tydens sy jaarverblyf in Rome (387-388), raak Augustinus nie spesifiek ons onderwerp aan nie maar skryf hy tog uitbundig oor die naasteliefde (vgl. DQA 34.78), 'n gegewe wat vir ons tema baie belangrik is. Hy wys daarop dat nie sondaars nie maar sondes gehaat moet word en dat ons bereid moet wees om elkeen te help, ook diegene wat ons kwaad aangedoen het of diegene wat sou wens dat ons kwaad aangedoen word. "Dit is ware religie, dit is volmaakte religie, dit alleen is religie" (Haec est vera, haec perfecta, haec sola religio). Die enigste ware vryheid is om God te behaag deur Hom te dien.

Ons tema word deur Augustinus baie uitdruklik aangesny in sy geskrif $D e$ moribus ecclesiae catholicae (DME)(388) waarin hy die katolieke etiek teenoor dié van die Manicheïsme uitspel en die dubbele liefdesgebod bespreek. Die verhouding van die mens tot God is allesoorheersend. Die vervolmaking van al ons goeie dinge en ons volmaakte goedheid is God (Deus est nobis summum bonum) (DME 8.13). Die begeerte na geluk(-saligheid) is die begeerte na God; om God te bereik is geluk(-saligheid) (DME 11.18). En dan, met verwysing na 2 Korintiërs 4:18, volg die veelbesproke uitspraak: "God alleen moet liefgehê/ bemin word; en hierdie hele wêreld, dit is alle sinlike dinge, moet verag word, terwyl hulle nogtans gebruik moet word soos hierdie lewe noodsaak" (Amandus igitur solus Deus est: omnis vero iste mundus, id est, omnia sensibilia contemnenda; utendum autem his ad huius vitae necessitatem) (DME 20.37). Die vraag ontstaan of daar in hierdie siening nog ruimte is vir ware naasteliefde en 'n regte waardering van aardse goed. Augustinus bring die self- en naasteliefde ter sprake binne die konteks van die liefde tot God. Daar is vir hom geen sekerder tree in die rigting van liefde tot God nie as die liefde van mens tot mens (DME 26.48). Met 'n beroep op 1 Korintièrs 6:11-20 en 1 Korintiërs 7:1-7 verwerp Augustinus die Manicheistiese bewering dat die huwelik en besittings nie bedoel sou wees vir Christene wat deur die doop hernuwe is nie (DME 35.78); Christene "gebruik" asof hulle "nie gebruik nie" (1 Kor. 7:31) (DME $35.77,80)$.

'n Volgende geskrif wat hier aandag moet ontvang, is Augustinus se De diversis quaestionibus 83 . Hierin (DD 83,30 ) betoog hy dat die verskil tussen geniet en gebruik (fruendum et utendum) korrespondeer met dié tussen die eerbare en die 
bruikbare (honestum et utile). Alhoewel iemand oppervlakkig kan beweer dat alle eerbare dinge bruikbaar is, en alle bruikbare dinge eerbaar nie, is dit tog meer korrek om "eerbare dinge" te bestempel as dit wat gesoek moet word ter wille van sigself (propter se ipsum), terwyl "bruikbare dinge" dit is wat met ander dinge in verband gebring moet word (utile autem quod ad aliud aliquid referendum est). Augustinus wys dan daarop dat daar geen spanning tussen die eerbare en die bruikbare bestaan, soos sommige onkundiges wel meen nie. Wat hom betref, hy geniet dit waarin hy hom verlustig, en gebruik dit wat in verband staan met dit waarin hy hom verlustig. Daarom bestaan alle menslike perversie daarin dat begeer word om te gebruik wat geniet moet word en om te geniet wat gebruik moet word (Omnis itaque humana perversio est ..., fruendis uti velle atque utendis frui). Daarteenoor bestaan die goeie en deugdelike orde immers daarin om te geniet wat geniet moet word en om te gebruik wat gebruik moet word. Verder voer Augustinus (DD 83,30) aan dat wat geniet moet word, is onsigbare, geestelike skoonheid; die sigbare en bruikbare, wat die Voorsienigheid voorsien, kan gebruik word soos dit benodig word. Iemand kan nie iets reg gebruik indien hy nie weet waarmee dit in verband staan nie, en wie nie iets reg gebruik nie, misbruik dit. Hierdie in-verband-bring-met (oriëntering op) bestaan in die genieting/verlustiging van God (fruatur deo), want slegs dán is die mens gelukkig. Alle dinge is geskape ter wille van die gebruik deur die mens.

\subsection{Uitsprake tydens die vroeĕ Afrikaanse periode (389-396)}

In hierdie verband kan na twee geskrifte verwys word waarvan die eerste De vera religione (voortaan DVR) is, geskryf in Tagaste (389-391) en opgedra aan sy beskermheer Romanianus. Hierin (DVR 47.91) skryf Augustinus dat die mens wat met God verenig is sy vriende "gebruik" (utitur amico) om hulle liefde te beantwoord, dat hy sy vyande "gebruik" (utitur inimico) ter wille van geduld, ja, soveel (mense) as wat hy kan, "gebruik" hy met die doel om goed te doen, hy "gebruik" alle mense in die sin dat hy teenoor almal welwillend is (utitur omnibus ad benevolentiam). Alhoewel hy nie tydelike dinge liefhet nie, gebruik hy die dinge reg en versorg hy mense volgens die eise van die lewe, selfs al is hy nie in staat om teenoor almal ewe behulpsaam te wees nie.

Uitgebreider aandag verdien De doctrina Christiana (DDOC) waarvan die eerste deel (1-3.24) in 396 voltooi is en die latere deel (3.25-4.31) in 426. Die essensie van hierdie boek handel oor die interpretasie en verklaring van die Bybel. Veral boek I gee veelvuldige aandag aan die konsepte uti en frui. Daar is sommige dinge, sê Augustinus (DDOC 1.1.3), wat geniet moet word (fruendum est), ander wat gebruik moet word (utendum), en ander wat geniet en gebruik moet word. Daardie dinge wat voorwerpe van genot is, mak ons gelukkig en daardie dinge wat voorwerpe van gebruik is, help en ondersteun ons op ons weg na geluk sodat ons daardie dinge wat ons gelukkig maak, kan verkry en behou. Want om iets te 
geniet, vervolg hy (DDOC 1.1.4), is om met liefde daaraan vas te hou ter wille van daardie ding self (Frui enim est amore alicui rei haerere propter seipsam). Om iets egter te gebruik, is om iets aan te wend ten einde dit te verkry wat jy liefhet/begeer, met die voorbehoud dat dit werd is om bemin te word; 'n onwettige gebruik moet eerder as misbruik getipeer word. In hierdie konteks gebruik Augustinus die beeld van 'n swerwer in die buiteland wat na sy vaderland verlang en daarheen wil terugkeer maar verswelg word deur al die genietinge wat hy onderweg teëkom.

Dit staan vir Augustinus bo alle twyfel vas dat die objekte van frui die Vader en die Seun en die Heilige Gees is, die een, ewige, onveranderlike en magtige God (DDOC 1.1.5). Slegs daardie dinge, vervolg hy (DDOC 1.22.20), is ware voorwerpe van genieting/verlustiging wat ewig en onveranderlik is; ander dinge is vir gebruik, sodat ons tot die volle genieting (van die vorige) kan kom. Die mens, egter, wat ander dinge geniet en gebruik, is self ook 'n ding en so is daar die groot vraag (magna quaestio) of die mens, geskape na die beeld van God, homself mag geniet of gebruik, of albei. Augustinus konkludeer dat dit vir hom wil voorkom (videtur) of die naaste bemin moet word ter wille van iets anders (propter aliud).

Augustinus benader die tema ook vanuit die gedagte van selfliefde. Niemand, sê hy (DDOC 1.22.21), behoort homself lief te hê ter wille van homself nie maar ter wille van Hom wat die ware voorwerp van genieting/verlustiging is. Die mens wat homself ter wille van homself liefhet, vergeet sy verhouding tot God en verval in 'n (foutiewe) selfingekeerdheid (vgl. Luther se incurvatum in se), en word dus nie in beslag geneem deur dit wat onveranderlik is nie. So iemand geniet nie ten volle nie, want dit is beter as iemand se hart gerig is op en sy gevoelens in beslag geneem word deur die onveranderlike goeie. Indien 'n mens jouself nie ter wille van jouself nie maar ter wille God moet liefhê, dan behoort ook die naaste nie ter wille van homself nie maar "ter wille van God" (propter Deum) bemin te word. Die liefdesgebod van Matteus 22 vra immers dat ons slegs Gód met alles moet liefhê. Die heilige en regverdige mens is vir Augustinus (DDOC 1.27.28) daardie mens wat dinge reg waardeer, wat 'n geordende liefde het: hy het nie lief wat nie bemin behoort te word nie; hy laat ook nie na om te bemin wat bemin behoort te word nie. Ook bemin hy nie daardie dinge méér wat minder bemin behoort te word nie; hy bemin ook nie daardie dinge gelykwaardig wat of minder of meer bemin behoort te word nie en hy bemin ook nie daardie dinge minder of meer wat gelykwaardig bemin behoort te word nie. Elke mens moet ter wille van God bemin word (diligendus est propter Deum), maar God moet ter wille van homself bemin word (Deus vero propter seipsum). As God dus meer as enige mens bemin behoort te word, dan behoort elke mens ook God meer as homself lief te hê. So gesien, behoort ons ook iemand anders meer lief te hê as ons eie liggaam, omdat alle dinge in verband met God (propter Deum) 
bemin behoort te word, en iemand anders kan met ons gemeenskap hê in die genieting van/verlustiging in God, terwyl ons eie liggaam nie kan nie; want die liggaam leef slegs deur die siel en dit is deur die siel dat ons ons in God verlustig (fruimur Deo).

Vanselfsprekend ontstaan in hierdie opsig die vraag hoe God ons liefhet: gebruik Hy ons of geniet Hy ons (ut nobis utatur an ut fruatur)? (DDOC 1.31.34). As Hy ons geniet, dan benodig Hy iets goeds wat van ons afkomstig is, en dit kan geen regdenkende mens beweer nie, aangesien al ons goeie (dinge) ó Homself is of van Hom afkomstig is. Daarom moet gesê word (vgl. Ps. 15:2) dat God ons nie geniet nie maar gebruik, want indien Hy ons nie geniet nie en ook nie gebruik nie, is dit nie duidelik hoe Hy ons liefhet nie. Augustinus (DDOC 1.32.35) wys onmiddellik daarop dat God dinge anders gebruik as wat mense dinge gebruik. Die gebruik wat God van ons maak, is nie tot sy voordeel nie maar tot ons s'n. Wanneer ons iemand bystaan en help, dan doen ons dit doelbewus tot sy voordeel. Op 'n onverklaarbare wyse bevoordeel sulke dade ook onsself, want God beloon ons deernis teenoor mense in nood. Ons grootste beloning is egter dat ons Hom volkome mag geniet (ons in Hom mag verlustig) en dat almal van ons wat ons in Hom verlustig, mekaar volkome in Hom mag verlustig (et omnes qui eo fruimur, nobis etiam invicem in ipso perfruamur).

Wanneer iemand hom in God verlustig in ' $\mathrm{n}$ mens, dan is dit 'n verlustiging in God eerder as in 'n mens (Cum autem homine in deo frueris, deo potius quam homine frueris) (DDOC 1.33.37). Want kyk, sê Augustinus aan die hand van die Vulgata (sy kennis van Grieks was swak), Paulus verlustig hom in Filemon "in die Here" (v. 20). "Om jou te verlustig in" ("om te geniet") se inherente betekenis lê baie naby aan "om met liefde te gebruik" (frui cum dilectione uti). Augustinus herhaal dan wat hy eerder gesê het (in DDOC 1.1.5) dat hierdie (laaste) soort verlustiging slegs gesoek moet word in die Triniteit, die hoogste en onverandelike goeie.

Augustinus (DDOC 1.35.39) vat saam wat hy tot dusver in De doctrina Christiana gesê het, en wat volgens hom die Skrif ons leer: daar moet liefde wees vir daardie ding (Ding) waarin ons ons kan verlustig/wat ons kan geniet (fruendum est), asook liefde vir 'n ding wat hierdie verlustiging/genieting (in/van Hom) met ons kan deel, want daar is geen noodsaak van 'n gebod dat elke mens homself moet liefhê nie. Die mens moet die tydelike bedeling dus nie met 'n ewige nie maar met 'n verbygaande liefde bemin - ter wille van die einddoel wat wag.

Wanneer Augustinus in boek 3 'n definisie gee van caritas en cupiditas, herhaal hy sy siening van uti en frui (DDOC 3.10.16). Caritas word dan omskryf as daardie sielsingesteldheid wat gerig is op verlustiging in (genieting van) God (fruendum Deo) ter wille van Homself (propter ipsum), asook die genieting van 
jouself en jou naaste ter wille van God. Cupiditas daarenteen is daardie sielsingesteldheid wat gemik is op genieting van jouself en jou naaste, asook ander stoflike dinge, buite God om.

\subsection{Uitsprake tydens die latere Afrikaanse periode (396-430)}

In hierdie verband moet drie van Augustinus se bekendste werke genoem word, te wete sy Confessiones (C) (397-401), De Trinitate (DT) (399-419) en De civitate Dei (DCD) (413-427).

In sy Confessiones, wat Augustinus begin skryf het kort na sy bevestiging as biskop in Hippo in 396, is daar 'n enkele verwysing wat ons aandag vra. In boek 4.9.14 handel hy oor die waarde van menslike vriendskap en merk dan op: Gelukkig is hy wat God liefhet, en sy vriend in God en sy vyand om Gods wil (propter te). Want alleen hy verloor geen dierbare wanneer daardie dierbare "in God" dierbaar is, want net God is onverliesbaar. Ook hier val die aksent daarop dat die naaste "in God" bemin moet word.

Ook in sy beroemdste dogmatiese boek, De Trinitate, resoneer ons onderwerp. Augustinus wys ook hier op die onderskeid tussen cupiditas (begeerte) en caritas (liefde) (DT 9.8.13). Hy wil geensins beweer dat 'n geskape ding nie bemin (amanda) mag word nie; indien daardie liefde (vir die skepsel) egter op God gerig/georiënteer is, dan is dit nie cupiditas nie maar caritas. Wanneer 'n geskape ding ter wille van homself bemin word, is dit cupiditas, en dan help dit ook nie om dit te "gebruik" (utentem) nie, maar bederf dit 'n mens wanneer hy dit "geniet" (fruentem). Wanneer 'n geskape ding gelykwaardig of ondergeskik is aan ons, moet ons die ondergeskikte gebruik (utendum) met betrekking tot God, maar ons moet die gelykwaardige slegs in God geniet (fruendum). Want soos wat 'n mens jouself behoort te geniet, nie in jouself nie maar in Hom wat jou geskape het, so ook hom wat 'n mens soos jouself liefhet. Ons moet daarom sowel onsself as ons broeders in die Here geniet (Et nobis ergo et fratibus in Domino fruamur).

Ook in DT 10.11.17 kom die onderskeiding tussen uti en frui na vore. "Om te gebruik" (uti), sê Augustinus, is om iets onder die gesag van die wil te plaas; "om te geniet" (frui) is om met vreugde (cum gaudio) die wérklike ding (en nie dit waarop jy hoop nie) te gebruik. Daarom moet gesê word dat hy wat "geniet" ook "gebruik", want hy gebruik iets wel-willend wat hom ook volkome (as einddoel) bevredig. Andersyds geld dat nie elkeen wat iets "gebruik" dit ook "geniet" nie, naamlik wanneer hy wel-willend iets gebruik nié ter wille van die ding self nie maar ter wille van iets anders.

In De civitate Dei handel Augustinus veelvuldig oor uti en frui. In DCD 8.8, waar hy aanvoer dat die Platoniste kundige etici is, wys hy op die "hoogste goed" 
wat beskryf kan word as daardie ding wat nie verder gesoek hoef te word ten einde gelukkig te wees nie; maar dan moet al ons dade daarheen wys, en dan moet daardie ding ook gesoek word nié ter wille van iets anders nie maar ter wille van homself (et quod non propter aliud, sed propter se ipsum appetentes). Daarom word dit ook einddoel (finis) genoem, aangesien ons ander dinge ter wille van hierdie een ding begeer en hierdie een ding ter wille van homself (propter ipsum). Tereg sê Plato dat die ware en hoogste goed God is. Niemand is geluk(-salig) wat nie dit geniet wat hy liefhet nie; hy wat God liefhet, is gelukkig in die genieting van/verlustiging in God (fruens Deo).

In DCD 11.25 duik die uti-frui-tema weer op in verband met die gebruik van aardse goed. Ons "geniet" dit wat ons in sigself verheug, afgesien van ander doeleindes, en ons "gebruik" daardie dinge wat ons met die oog op hoër doeleindes begeer. Tydelike dinge moet dus eerder "gebruik" (utendum) as "geniet" (fruendum) word, sodat ons waardig mag wees om die ewige dinge te kan geniet; nié soos daardie dwase wat graag geld geniet en God gebruik, wat nie geld spandeer ter wille van God nie, maar God eer ter wille van geld.

In DCD 15.7 karakteriseer Augustinus die aardse stad as 'n stad wat God of gode vereer en dan hoop om met die hulp hiervan oorwinnend en in aardse vrede te regeer, nie gedryf deur liefdevolle sorg nie maar deur heerssug (die konteks is die geskiedenis van Kain en Abel). Hierop volg dan die beroemde uitspraak: "Goeie mense gebruik naamlik die wêreld om God te kan geniet, daarteenoor wil slegte mense Hom gebruik om die wêreld te geniet" (Boni quippe ad hoc utuntur mundo, ut fruantur Deo: mali autem contra, ut fruantur mundo, uti volunt Deo).

In DCD 15.22 gaan Augustinus in op die betekenis van die vermenging van die seuns van God met die dogters van mense (Gen. 6). In hierdie verband noem hy dat liggaamlike skoonheid inderdaad 'n geskenk van God is, dit is sy handewerk, maar dit is tydelik, vleeslik, goedheid van 'n laer gehalte, en hierdie soort goed word op 'n verkeerde manier bemin wanneer dit verkies word bo God, die ewige, geestelike en onveranderlike goed. Op dieselfde wyse het hebsugtiges 'n verkeerde liefde vir goud wanneer hulle dit bo geregtigheid verkies - die sondaar is egter nie die goud nie maar die mens. Alle geskape dinge is goed, maar dit kan op 'n slegte of regte manier bemin word; dit word op 'n regte manier bemin wanneer dit "ordelik" bemin word en op 'n slegte manier wanneer dit "onordelik" bemin word. Wanneer die Skepper waarlik bemin word, dit wil sê dat Hyself bemin word en nie iets anders in sy plek nie, dan kan daar geen verkeerde liefde wees nie. Ook die liefde self moet ordelik bemin word, want ons doen goed om dit lief te hê wat ons goed en deugsaam laat lewe. Deug kan kort en goed gedefinieer word as die (regte) orde van liefde (ordo est amoris).

Besondere aandag moet aan Boek 19 van De civitate Dei bestee word, aangesien Augustinus ons onderwerp hierin herhaaldelik aan die orde stel. Hy wys daarop 
(DCD 19.1.1) dat filosowe veel gediskusseer het oor die vraag in verband met die einddoel van die goeie en die kwade (vgl. Cicero) asook die vraag wat die mens eintlik gelukkig maak. Dan merk Augustinus op dat die einddoel van ons "goed" daardie ding is ter wille waarvan ander dinge nagestreef/begeer moet word (appetenda), terwyl daardie ding ter wille van homself nagestreef/begeer moet word (ipsum autem propter seipsum). Daarteenoor is die einddoel van die kwade daardie ding ter wille waarvan ander dinge vermy/links laat lê moet word, terwyl daardie ding ter wille van homself vermy moet word. Augustinus (DCD 19.1.2-3) verwys dan verder na die boek van Varro De Philosophia (waarvan verder niks bekend is nie) waarin hy 288 filosofiese opinies in verband met geluk onderskei. Varro verwerp alle standpunte behalwe dié van die Ou Akademie (Plato). 'n Mens filosofeer om gelukkig te wees en dit wat gelukkig maak, is die hoogste goed. Augustinus voeg egter by dat die vraag nie net is watter einddoel nagestreef moet word nie, maar ook of ons in die werklike bestaan van daardie einddoel glo, met ander woorde of dit die wáre goed is.

Vervolgens word Varro se standpunt in verband met ware geluk en die hoogste goed behandel (DCD 19.3). Varro argumenteer dat hierdie vraag alleen reg beantwoord kan word as geantwoord word op die vraag wat die mens is. Die mens, sê hy, is siel en liggaam. Gevolglik moet die hoogste goed van die mens, dit wat die mens gelukkig maak, uit goedere van siel en liggaam bestaan. Stoflike en geestelike goedere moet dus ter wille van hulleself gesoek word. Van alle goedere is deug egter die belangrikste. Watter belang, vra Augustinus nou, het hierdie siening vir Christene (DCD 19.4)? Hierop lui die antwoord dat die ewige lewe die hoogste goed, die ewige dood die hoogste kwaad is; om die ewige lewe te verkry en die ewige dood vry te spring, moet die mens op die juiste wyse lewe - iets wat nie in eie krag moontlik is nie. Die burgers van die Godstad (DCD 19.17) is pelgrims in hierdie wêreld en maak van die wêreld gebruik, maar slegs in soverre as wat dit nie die geloof en godsdiens skaad nie.

\subsection{Samevatting}

- Oor die oorsprong van die woorde uti en frui loop die menings grootliks uiteen. Hoogs waarskynlik is albei begrippe van Grieks-filosofiese oorsprong en stam hulle nie uit die Bybel nie. Gevolglik moes Augustinus dit in terme van die Skrif probeer herdefinieer. Daar kan gedebatteer word oor die vraag of dit verstandig - en teologies geslaagd - was om hierdie denkproses uit te voer. Augustinus moes egter binne die konteks van sy tyd, in gesprek met sy tyd, in die taal van sy tyd die evangelie en die implikasies daarvan duidelik maak - dit alles binne die konteks van die sentraalstelling van die liefdesprinsipe in sy teologie en etiek.

- Ten opsigte van die manier waarop asook die geskrifte waarin bogenoemde terme voorkom, moet daarop gewys word dat die terme, wat sowel in die 
vroeë as latere geskrifte te vind is, 'n bepaalde ontwikkelingsgang deurgemaak het. Augustinus het die begrippe gebruik om die inhoud van verhoudings aan te dui, die mens se verhouding tot God, die mens se verhouding tot homself, die mens se verhouding tot die naaste en die mens se verhouding tot die geskape dinge. Dit gaan vir Augustinus om 'n juiste waardering van die totale geskape werklikheid, wat nooit los van God om mag plaasvind nie maar altyd met verwysing na en in verhouding tot God (referre). Die liefde vir God is totaal, radikaal en allesomvattend.

- Augustinus kan gekritiseer word dat hy in sy formulering soms die indruk laat dat God ten koste van die mens bemin moet word. Tog moet verreken word dat die twee begrippe binne 'n sterk teosentriese raamwerk gehanteer is om die verabsolutering van die skepselmatige te voorkom (vgl. De Kruijf, 1994b: 4). 'n Mens mag, op grond van die Skrif, nie die Absolute relatief liefhê en die relatiewe absoluut nie. Dit is nie geoorloof om die naaste met die hele hart, met die hele siel, met die hele verstand en met alle krag lief te hê nie. 'n Mens het God eenvoudig anders lief - met alles - as wat jy jou naaste liefhet - soos jouself. Die vraag kan egter gestel word of dit korrek is om die mens se liefde vir God met die begrip frui te tipeer. Tereg impliseer die siening van Augustinus dat dit nie sin maak wanneer die mens in (die genieting van) hierdie lewe opgaan terwyl daar nog 'n ewigheid van genot wag nie.

- Dit was nooit Augustinus se bedoeling dat die naasteliefde oneg, half of halfhartig moet wees nie - hoewel sy formulerings soms daardie indruk skep. In hierdie verband kan onder andere gedink word aan sy beroemde uitspraak in Tractatus in Epistolam Johannis ad Parthos 7.8 (TEJ): "Het lief en doen wat jy wil" (Dilige, et quod vis fac). Hierdie uitspraak beteken seker nie 'n vrypas tot alles en nog wat nie, maar beteken, soos Augustinus self verklarend byvoeg: indien jy vrede onderhou, doen dit in liefde; as jy uitroep, doen dit in liefde; as jy iemand reghelp, doen dit in liefde; as jy ontsien, doen dit in liefde; van hierdie wortel (van liefde) kan niks anders tot gevolg hê behalwe dit wat goed is nie (non potest de ista radice nisi bonum existerc) (vgl. ook De Kruijf, 1994a:59).

Op een punt egter het Augustinus die naasteliefde onderwaardeer en dit is ten opsigte van sy verwerping van enige vorm van genot by seksuele gemeenskap in die huwelik. Die huwelik en geslagsorgane, so oordeel hy, is slegs daar vir prokreasie en elke vorm van geslagsgemeenskap daarbuite om is per definisie sondig.

- Die verwysing na selfliefde in die Groot Gebod probeer Augustinus veilig stel deur enersyds te praat van 'n liefde tot die self "in God", en dit andersyds te 
hanteer as 'n maatstaf vir naasteliefde (vgl. O'Donovan, 1980). In elk geval is daar geen sprake van 'n opdrag tot selfliefde nie.

- Dit is belangrik dat Augustinus ook die mens se verhouding tot die geskape dinge betrek. Maar moet dit met die term "liefde" in verband gebring word, selfs as $u t i$-liefde? Wat van ander begrippe wat hierdie verhouding tipeer begrippe soos oppas, versorg en bewaar? Die teologie van Augustinus bied min aanknopingspunte vir die hantering van moderne ekologiese vraagstukke.

\section{Augustinianisme}

Onder Augustinianisme word daardie denklyn verstaan van hulle wat die denke van Augustinus verder ontwikkel het, veral in die gereformeerde Protestantisme. Daarmee word natuurlik geensins ontken dat Augustinus ook binne die RoomsKatolieke tradisie 'n groot invloed uitgeoefen het nie (vergelyk bv. Grabowski 1957 se jubelende boek oor Augustinus). Dit was nie net Luther wat van Augustinus gesê het meus totus, en Calvyn totus noster nie (Van Oort, 1989:66), maar ook pous Pius IX het van hom gesê noster est (Grabowski, 1957:XIV).

Weens gebrek aan ruimte gee ons hier slegs aan enkele reformatoriese teoloë aandag en dan ook net ten opsigte van enkele raakpunte, veral ten opsigte van die gebruik van aardse goedere.

\section{- Calvyn 4}

Die eerste teoloog wat ons hier aan die orde wil stel, is Calvyn, iemand wat hom in sy teologie herhaaldelik op Augustinus beroep het. Dit val op dat waar Augustinus (SO 1.7) gesê het dat hy van niks anders wil weet en niks anders wil liefhê as "God en die siel" nie, Calvyn sy Institusie (1.1) open met 'n breër inset naamlik dat die somtotaal van alle wysheid geleë is in kennis van God en kennis van onsself. Hierdie "self" is 'n verloste sondaar, 'n vreemdeling en pelgrim op weg na hemelse saligheid. In vergelyking met die toekomstige lewe, is hiérdie aardse lewe van verbygaande waarde. Christene moet die wêreld "versaak" (Inst. 2.15.5), hulle moet die teenswoordige lewe "verag" en "vertrap" (Inst. 3.9.1; 3.10.4), ja, hierdie wêreld moet vir hulle "waardeloos" word (Inst. 3.9.2). Die beste pad vir Christene is daardie een wat bestaan in "veragting vir die huidige lewe en die oordenking van die hemelse onsterflikheid" (Inst. 3.10.4). Dit is "kragtige taal" (De Kruijf, 1994b:7) sou 'n mens kon sê, ja, dalk "te sterk" (Velema, 1974b:35).

Tog moet verreken word dat Calvyn van bestaande uitdrukkings gebruik gemaak het - soos ons vandag nog doen: vergelyk die formulering van die Doops-

4 By die bespreking van Calvyn is gebruik gemaak van sy Opera Selecta, asook van die Afrikaanse vertaling (H.W. Simpson) van sy Institusie - kyk bibliografie. 
formulier dat ons "die wêreld moet versaak" - en dat hy nie daarmee bedoel het dat 'n Christen sy aardse roeping moet verwaarloos nie. Daarvan getuig sy afwysing van die Doperse wêreldmyding. Gelowiges mag nie die huidige lewe op so 'n manier verag "dat hulle 'n afsku daarvan of ondankbaarheid teenoor God verwek nie" (Inst. 3.9.3); "ons moet die lewe op aarde sekerlik nooit haat nie, behalwe in soverre dit ons aan die sonde onderhewig hou ..." (Inst. 3.9.4).

In sy Institusie 3.10 gee Calvyn spesiale aandag aan die gebruik van aardse goed. Alle seëninge van die lewe is gawes van God, maar die mens is 'n pelgrim op weg en hy moet waak teen onbeheerstheid en oordadigheid en die gawes van God reg gebruik (Inst. 3.10.1). Hy mag gebruik wat hy nodig het én wat hy kan geniet - dinge soos klere, wyn, olie, blomme, goud, silwer, ivoor en marmer (Inst. 3.10.2). Die aardse goed moet 'n bydrae lewer tot ons roepingsvervulling, dit moet lei tot kennis van, dankbaarheid teenoor en liefde en eerbied vir die Gewer daarvan (Inst. 3.10.3). Gelowiges moet deugde soos geduld, matigheid en tevredenheid beoefen en moet as rentmeesters altyd bereid wees om rekenskap te gee (Inst. 3.10.4-5). Calvyn probeer om met sy roepingsteologie die uiterstes van asketisme en materialisme te vermy. Alles op aarde mag gebruik word maar dan tot eer van God en tot welsyn van die naaste.

Hoewel daar hier en daar by Calvyn spore te sien is van 'n Platonies-dualistiese denkskema, het sy noue aansluiting by die Skrif hom daarvan weerhou om daarvan 'n slagoffer te word. Daarby het hy Augustinus se hantering van die begrippe $u t i$ en frui nie oorgeneem nie.

\section{- Brillenburg Wurth}

'n Tweede teoloog wat ons hier kortliks wil aanhaal, is Brillenburg Wurth. Wurth vind in sy etiek sterk aansluiting by Calvyn en beskryf die Christelike lewe as 'n lewe van diens aan God, die naaste en die samelewing. Van 'n ongesonde askese is daar geen sprake nie (Wurth, 1957:230-231). In verband met die vraag hoe besittings gebruik mag word, merk hy op dat 'n juiste waardeskaal hier nodig is en dit word gevind wanneer uitgegaan word van die "een ding wat nodig is" (Luk. 10:42) (Wurth, 1951:206). Van hieruit kom daar ruimte vir die gebruik van die nodige en die nuttige, die aangename en die skone in die lewe (1951:207). Wurth (1951:205) herinner ook aan die besondere uitspraak van Max Scheler: die evangelie verskaf aan 'n mens 'n maksimum genot met 'n minimum aan genotmiddele, terwyl die kapitalisme aan ' $n$ mens ' $n$ minimum van genot verskaf met 'n maksimum aan genotmiddele. Weelde is dikwels nie 'n ongemengde seën nie, maar dit kan ook in dankbaarheid teenoor God en op die regte wyse aangewend word (Wurth, 1951:207-209; vgl. Wurth, 1934:73-85). Die Christelike sedeleer impliseer geensins die vernietiging van lewensgeluk nie, maar soek dit op die regte plek: "Er is niets, dat het leven armer maakt, dan nemen, en niets, dat het rijker maakt dan geven en arbeiden en dienen" (Wurth, 1947:87). Die 
eties-goeie moet ook nooit gesoek word in dit wat die mens se lewe, sy genot of sy geluk bevorder nie, maar in die sedewet van God (Wurth, 1947:92). Is die Christelike sedeleer dan inhumaan? Allesbehalwe. Die mens kan egter nooit waarlik menslik en gelukkig wees los van God om nie. Dit geld ook van die verhouding tot die naaste. "Ik moet hem liefhebben met het oog op zijn bestemming, met het oog op wat hij behoort te worden" (Wurth, 1947:102). Dit klink suiwer Augustiniaans.

\section{- Van Ruler}

In die reformatoriese teologie is daar waarskynlik geen teoloog wat so 'n hoë waardering van die aarde en aardse lewe ontwikkel het en so radikaal met die Grieks-Platoniese dualistiese denkwyse gebreek het as die teoloog Van Ruler 5 nie (vgl. 1972a:9-31). Vir hom is die stoflike net so belangrik as die geestelike (1972a:11). Al is dit so dat alles om die versoening en regverdiging draai, sê hy (1972a:13), gáán alles om die verloste skepping en die ryk van heerlikheid. Die Christelike geloof bring ons tot radikale materialisme sodat gesê moet word: die stof is heilig, die eintlik heilige wat daar is (1972a:16, 18; vgl. 1972b:39-42). Daarom moet dit ook "geniet" word. Gevolglik wys Van Ruler (1972a:17) Augustinus se onderskeiding eksplisiet af, naamlik dat 'n mens net God en die ewige dinge mag geniet (frui) en dit nog inwendig, en dat die buitewêreld slegs gebruik (uti) mag word. Hy (1972a:17) ontdek in hierdie siening van Augustinus iets godslasterlik: 'n mens laster die Skepper omdat jy sy skepping benede die maat vind. Van Ruler (1972a:17) tipeer hierdie aanpak (van homself) en aksent op die skeppingsmotief as 'n "revolutionering van het christelijk geloof". Vir die aardse lewe, en alles wat daarmee saamgaan (stoflikheid, liggaamlikheid, enkelheid, geslagtelikheid, tydelikheid, gemeenskaplikheid en historisiteit) het hy slegs die hoogste waardering: die aardse lewe is die eintlike en die enige (1972a:23). "Het ware geestelijke, bevindelijke, innerlijke leven is de beleving van het tijdelike leven voor Gods aangezicht, als lofzeggende dienst" (1972a:28). Die Christelike toekomsverwagting handel ook nie oor die vernuwing van 'n ánder aarde nie maar van hiérdie aarde. Die lewe en die wêreld mag - moet dus geniet word. "Ik zou op dit punt bewust willen breken met een eeuwenoude, christelijk-europese traditie", naamlik Augustinus se siening van uti en frui (1972a:30).

5 Dit val op dat die aardse werklikheid en dié aardse lewe ook in die teologie van die Lutherse tooloog, Dietrich Bonhoeffer, 'n prominente plek inneem, veral in sy gevangenskapsbriewe (vgl. Bonhoeffer, 1968:58, 68, 74, 111, 129, 141, 142, 146). Veral bekend is sy uitspraak (1968:74) dat dit smaakloos is om te beweer dat ' $n$ man in die arms van sy vrou na ' $n$ ander lewe sou moct verlang en dat dit in elk geval nie die wil van God is nie; as God ons wil laat genict van 'n oorweldigende aardse geluk, dan moet ons nie vromer as God wees nie ... God sal aan hom wat Hom dankbaar vind in aardse geluk, wel comblikke gee waartydens hy herinner sal word dat die aardse maar iets voorlopigs is. En ook (1968:111): God en sy ewigheid wil bemin word met die hele hart, maar nie so dat die aardse liefde daaronder ly of verswak word nie ... 
Hierdie standpunt van Van Ruler het natuurlik bepaalde vrae opgeroep. Het hy Augustinus korrek vertolk? Kom die Bybelse beeld van die Christen as pelgrim tot sy reg (De Kruijf, 1994b:11)? Word die interimskarakter van hierdie tydelike bestaan nie te veel gerelativeer nie (De Kruijf, 1994b:13)?

\section{- Velema}

'n Laaste voorbeeld wat ons hier wil noem, is Velema. In talle geskrifte het hy aandag gevra vir die Christelike lewe op aarde, vir Christen-wees in hierdie tyd (1974a), vir die Christelike lewe van vreemdelingskap (1974b), vir die Christelike lewe midde-in die maatskappy (1979), vir die Christelike lewe as heilige lewe (1985) - om slegs enkeles te noem. Velema (1974a:7-25; vgl. 1974b:59-70) wys op die gevare van 'n radikale solidariteit met die wêreld asook van 'n radikale antitese teenoor die wêreld; self hanteer hy die Bybels-dialektiese model van in die wêreld maar nie van die wêreld nie. Die tema van vreemdelingskap en pelgrimskap ontvang 'n swaar aksent. Die mens is op weg na die voltooide koninkryk; hy leef in die spanningsveld van die "alreeds" en die "nog nie". Hy kan die komende nuwe wêreld nie self realiseer nie, maar hy kan wel in die krag van die Heilige Gees tekens daarvan oprig (1974b:90-92). By Velema (vgl. 1974b:43) ontvang die kontinuîteit tussen die ou en nuwe wêreld 'n groter aksent as by Augustinus. 6

\section{Konklusie}

\section{Tussen hedonisme en asketisme}

Die Bybel leer dat die Christelike lewe voltrek word in die spanningsveld van sout-vir-die-aarde-wees (Matt. 5:13) enersyds, maar ook bywoner- en pelgrimwees (Heb. 11:13) andersyds. Reeds in die Ou Testament blyk dat Israel 'n volk op weg is na die Beloofde Land - en selfs nadat die Beloofde Land bereik is, blyk nogmaals dat die eintlike eindbestemming nog verder reik (Heb. 11:39-40). Hierdie tema word in die Nuwe Testament voortgesit - 'n tema waarop ons hier eerstens wil wys.

Ná die voltooiing van hierdie artikel het die studie van Velema (1996:11-44) oor die waardering van die aardse lewe onder my aandag gekom. Daarin maak hy tereg die opmerking dat ons waardenng van die aardse lewe bepaal word deur die voorstelling wat ons van God het (1996:36). Hy vertolk die goeie hantering van die begrippe gebruik en geniet binne die konteks van die cerste (of voorlaaste) en laaste dinge, maar nie so dat die eerste dinge gebruik en die laaste geniet word nie; wél so dat gebruik en geniet by cerste en laaste dinge - in albei bedelinge - ter sprake moet kom (1996:36). Hy beklemtoon verder die motiewe van vreemdelingskap, rentmeesterskap en mededeelsaamheid. Niks van dic skepping mag verabsoluteer word nie. Van 'n kultuurmandaat wil hy, vanuit 'n Christologiese benadering, nie veel weet nie - anders as Douma (Velema, 1996:32-33, 38). 


\subsection{Die Christelike lewe as 'n lewe van vreemdelingskap (anti-hedonisme)}

Die Bybel is daaroor duidelik dat die skema van hierdie wêreld verbygaan (l Kor. 7:31). Ons het in hierdie wêreld geen vaste verblyfplek nie maar is op soek na die toekomstige (Heb. 13:14; vgl. Gal. 4:26). Daar is geen Bybelboek waarin hierdie idee van die mens as vreemdeling op aarde so sterk ontwikkel is as in Hebreërs nie. Gelowiges het besittings wat beter en meer blywend is as aardse besittings (Heb. 10:34); op aarde is die mens slegs vreemdeling en bywoner en daarom op soek na 'n vaderland (Heb. 11:13-14) (vgl. Opperman, 1995:174-175, 209-213). Godsdiens is nie bedoel vir geldelike wins nie; ons het niks in die wêreld ingebring nie en ons kan ook niks daaruit wegneem nie (1 Tim. 6:6-7). Van Moses word getuig dat hy verkies het om liewer saam met die volk van God sleg behandel te word as om die kortstondige genieting (apolausin) van die sonde te hê (Heb. 13:25). Trouens, ook ten opsigte van die eindtyd waarsku Paulus teen sondige mense wat eerder liefde vir genot het as liefde vir God (2 Tim. 3:4). Ook by Petrus resoneer die gedagte van vreemdelingskap en daarom dring hy daarop aan dat gelowiges hulle nie moet oorgee aan sinlike begeertes wat 'n mens se lewe verwoes nie (1 Pet. 2:11). As verloste mens mag die Christen hom deur niks in hierdie wêreld laat verslaaf nie (1 Kor. 6:12). Hoewel die Christen in die wêreld is, is hy nogtans nie van die wêreld nie (Joh. 17:11, 14). Sy hart is waar sy skat is (Matt. 6:21). Hy leef "asof". Paulus het hierdie gedagte op 'n pragtige wyse in 1 Korintiërs 7:29-31 verwoord:

Die tyd is min. Van nou af moet dié wat getroud is, leef asof hulle nie getroud is nie; en dié wat bedroef is, asof hulle nie bedroef is nie; en dié wat bly is, asof hulle nie bly is nie; dié wat iets aankoop, asof hulle dit nie besit nie. Ja, dié wat met die dinge van die wêreld te doen het, moet leef asof hulle daar niks aan het nie, want hierdie wêreld soos ons hom ken, is aan die verbygaan.

Binne hierdie konteks moet die omstrede uitlating van Totius verstaan word, naamlik "die wêreld is ons woning nie". Hierdie woorde skep immers die indruk van 'n asketiese lewensideaal, wat by hom juis uitdruklik afgewys word (D'Assonville, 1994:24, 112). Totius het bogenoemde woorde gebruik binne die konteks van die Tweede Vryheidsoorlog (1899-1902), met ander woorde met verwysing na 'n verwoeste land, ' $n$ land vol kinder- en vrouegrafte en afgebrande plaashuise, ' $n$ land van dood en verwoesting (D'Assonville, 1994:69). Van só 'n wêreld sê hy tereg: Diè wêreld is ons woning nié. Maar die ander wêreld, die wêreld van reg en geregtigheid, van vrede en versoening, dáárdie wêreld is ons woning - en sal dit vir ewig wees.

Hierdie gedagte van vreemdelingskap word in die etiek van Augustinus breed uitgewerk en besonder beklemtoon, helaas ten koste van die tweede belangrike 
gedagte, naamlik dié van erfgenaamskap - hoewel daar by Augustinus van 'n Christelike vorm van eudaemonisme sprake kan wees (Clark, 1994:30). "Geluk" is die hoogste goed, maar dan nie sommer enige geluk nie, nee, slegs die geluk (-saligheid) in God.

\subsection{Die Christelike lewe as lewe van erfgenaamskap (anti-asketisme)}

Soos wat die Bybel geen hedonisme ken nie, so ken dit ook geen asketisme nie ('n saak waaraan Augustinus nie heeltemal ontkom het nie, hoewel die asketiese lewensideaal vir hom nooit doel op sigself was nie (Clark, 1994:83-93)). Die Skrif teken gelowiges ook as erfgename, erfgename van die aarde. Hulle wat die Here verwag, sal die aarde besit, lui Psalm 37:9. Vers 29 vervolg daarmee dat die regverdiges die aarde sal besit en vir ewig daarop sal woon - uitsprake wat natuurlik binne die konteks van die Ou-Testamentiese toekomsverwagting verstaan moet word. Ook aan die Nuwe Testament is hierdie gedagte nie vreemd nie: Salig is die sagmoediges want hulle sal die (nuwe) aarde beërwe (Matt. 5:5). Noudat Christus gekom het en sy Gees uitgestort is, beleef ons reeds iets van daardie nuwe wêreld ( 2 Kor. 5:17); God is nou reeds besig om alles nuut te maak (Op. 21:5). Die nuwe aarde wat God beloof het, is nie 'n ander aarde nie nie, maar hiérdie aarde totaal hernuwe (vgl. Heb. 11:10, 16) (Opperman, 1995:196197, 213-217).

Christene gaan nie in hulle aardse taak en plesier op nie - dan sou hulle hedoniste word; hulle konsentreer ook nie só op die hemelse toekoms dat hulle askete word nie. Die aarde en die aardse moet voluit beleef word met die oog op die toekomstige; die groot toekoms word verwag terwyl die aardse taak voluit nagekom word.

Genot en genieting is nie vreemd aan die Skrif nie - 'n gedagte wat by Augustinus baie verwaarloos is. Ook die aarde en aardse mag geniet word. Nie verniet nie sê die Prediker $(2: 24,3: 13,5: 17)$ dat om te kan eet en drink en die goeie te kan geniet, nie aan die mens self te danke is nie, maar gawes is uit Gods hand. In Prediker 9:9 gaan dit oor die genieting van die vrou van jou jeug en Hooglied (7:6) is een groot loflied op die regte liefdeslewe (maar dan nie allegories vertolk nie) (vgl. Spr. 5:18-19). Die Nuwe Testament beaam dit. Daar is wel 'n ernstige waarskuwing teen hulle wat ryk is en hulle hoop op die onsekerheid van rykdom in plaas van op God vestig; die Christelike hoop moet immers op Gód gebou word, dié God "wat alles ryklik aan ons gee om te geniet" (apolausin) (1 Tim. 6:17). Seksuele genot (binne die huwelik) is deel van die lewe, al is dit nie die volle lewe nie (1 Kor. 7:5) - 'n aspek wat Augustinus egter volledig verwaarloos het. (Sy seksuele en huweliksetiek is waarskynlik die swakste deel van sy etiek.) 
Uti en frui? Ja, hierdie begrippe is slegs bruikbaar as dit met Bybelse inhoud gevul en binne Bybelse konteks gebruik word. Daarsonder - gevul met Grieksfilosofiese inhoud - kan hulle tot groot ontsporings aanleiding gee.

\section{Bronnelys}

\section{Augustinus}

\subsection{Oorspronklike werke van Augustinus}

\section{Latynse tekste}

CSEL = BAUER, J.B., ed. 1992. Corpus Scriptorum Ecclesiasticorum Latinorum. Wenen Hölder-Pichler-Tempsky.

PL. = MIGNE, J-B., ed. 1841-1842. Patrologiae Cursus Completus (32-47). (Latinae). Parys : Migne.

\section{Spesifieke titels}

C $\quad=$ Confessiones (397-401) (PL 32:659-868)

DCD = De civitate Dei (413-427) (PL 41:13-804; PN 2:1-555)

DD83 = De diversis Quaestionibus 83 (388-395) (PL 40:11-100)

DDOC $=$ De doctrina Christiana (396/426) (PL 34:15-122, PN2:519-597)

DME = De moribus ecclesiae catholicae (388) (PL 32:1309-1344; PN 4:41-63)

$\mathrm{DQA} \quad=$ De quantitate animae (387-388) (PL 32:1035-1080)

DT = De Trinitate (399-419) (PL 42:820-1098; PN 3: 17-228)

DVR = De vera religione (389-391) (PL 34:121-172)

SO = Soliloquia (386-387) (PL 32:869-904; PN 7:537-560)

TEJ = Tractatus in Epistolam Johannis ad Parthos (413-414) (PL 35:1977-2062; PN 7:459-529)

\subsection{Vertaalde werke van Augustinus}

PN = SCHAFF, P. ed. 1978 e.v. Nicene and Post-Nicene Fathers of the Christian church (vol. 2-7). Grand Rapids : Eerdmans

AUGUSTINUS BELIJDENISSEN. 1965. Utrecht : Het Spectrum. (Vert. A. Sizoo.)

AURELIUS AUGUSTINUS. De stad van God. 1983. Baarn : Ambo. (Vert. G. Wijdeveld.)

SAINT AUGUSTINE. On Christian doctrine. 1958. New York : Macmillan. (Vert. D.W. Robertson.)

\section{Ander bronne}

ARENDT, H. 1929. Der Liebesbegriff bei Augustin: Versuch einer philosophen Interpretation. Berlin : Julius Springer.

BONHOEFFER, D. 1968. Verzet en overgave: Brieven en aantekeningen uit de gevangenis. Amsterdam: Ten Have. 
BRECHTKEN, J. 1975. Augustinus doctor caritatis. Sein Liebesbegriff im Widerspruch von Eigennutz und selbstloser Güte im Rahmen der antiken Glückseligkeits-Ethik. Meisenheim : Anton/Hain

BROWN, P. 1969. Augustine of Hippo: A biography. Berkeley : University of California Press.

BURNABY, J 1938. Amor Dei: A study of the religion of St. Augustine. London : Hodder \& Stoughton.

CALVIN, JOANNIS. 1957. Opera Selecta (Barth, P. \& Niesel, G.). München : Kaiser.

CALVYN, J. 1984/1986/1988/1992. Institusie van die Christelike Godsdiens (1-4). Potchefstroom : CJBF. (Vert. H.W. Simpson.)

CANNING, R. 1983a. Love of neighbour in St. Augustine: A preparation for or the essential moment of love for God? Augustiniana, 33:5-57.

CANNING, R. 1983b. The Augustinian uti/frui distinction in the relation between love for neighbour and love for God. Augustiniana, 33:165-231

CLARK, M.T. 1994. Augustine. London : Geoffrey Chapman.

D'ASSONVILLE, V.E. 1994. Dit is Totius: J.D. du Toit 1877-1953. Lynnwoodrif : Marnix.

DE KRUIJF, G.G. 1994a. Waakzaam en nuchter: Over christelijke ethiek in een democratie. Baarn : Ten Have.

DE KRUIJF, G.G. 1994b. Gebruiken en genieten: Een bruikbare onderscheiding in de christelijke ethiek. Leiden : Rijks Universiteit.

DUCHROW, U. 1970. Christenheit und Weltverantwortung: Traditionsgeschichte und systematische Struktur der Zweireichelehre. Stuttgart : Ernst Klatt.

GILSON, E. 1930. Der heilige Augustin: Eine Einführung in seine Lehre. Hellerau : Jakob Hegner.

GRABOWSKI, S.J. 1957. The Church: An introduction to the theology of Augustine. London : Herder Book.

HORN, C. 1995. Augustinus. München : Beck.

LORENZ, R. 1950/51. Fruitio dei bei Augustin. Zeitschrift für Kirchengeschichte, 63:75132.

LORENZ, R. 1952/53. Die Herkunft des augustinischen Frui Deo. Zeitschrift für Kirchengeshichte, 64:34-60.

MARROU, H-I. 1981. Augustinus und das Ende der antiken Bildung. Paderborn : Ferdinand Schöningh.

MAUSBACH, J. 1929. Die Ethik des heiligen Augustinus (I \& II). Freiburg : Herder. (Eerste uitgawe 1909.)

NYGREN, A. 1954. Eros und Agape: Gestaltwandlungen der christlichen Liebe. Gütersloh : Carl Bertelsmann.

O'DONOVAN, O. 1982. Usus and Fruitio in Augustine, De doctrina Christiana I. Journal of Theological Studies, 33:361-397.

O'DONOVAN, O. 1980. The problem of self-love in St. Augustine. New Haven : Yale University Press. 
OPPERMAN, W.C. 1995. Die motief van vreemdelingskap en vaderland in Hebreërs - 'n eksegetiese studie met toespitsing op Hebreërs 11:8-22. Potchefstroom : PU vir CHO. (Th.D.-proefskrif.)

PFLIGERSDORFFER, G. 1971. Zu den Grundlangen des augustinischen Begriffpaares utifrui. Wiener Studien, 84:195-224.

SCHOLZ, H. 1929. Eros und Caritas: Die platonische Liebe und die Liebe im Sinne des Christentums. Halle : Max Niemeyer.

TESELLE, E. 1970. Augustine the theologian. London : Burns \& Oates.

VAN DER ZWAAG, K. 1993. Augustinus, de kerkvader van het Westen. Leiden : Groen \& Zoon.

VAN OORT, J. 1989. Augustinus: Facetten van leven en werk. Kampen : Kok

VAN OORT, J. 1991. Jerusalem and Babylon: A study into Augustine's City of God and the sources of his doctrine of the two cities. Leiden : Brill.

VAN RULER, A.A. 1972a. Theologisch Werk V. Nijkerk : Callenbach.

VAN RULER, A.A. 1972b. Ik geloof: De Twaalf Artikelen van Geloof in morgenwijdingen. Nijkerk : Callenbach.

VELEMA, W.H. 1974a. Christen zijn in deze wereld. Kampen : Kok.

VELEMA, W.H. 1974b. Ethiek en pelgrimage: Over de Bijbelse vreemdelingschap. Amsterdam : Ton Bolland

VELEMA, W.H. 1979. Midden in de maatschappij: Over ethiek en sameleving. Kampen Kok.

VELEMA, W.H. 1985. Geroepen tot heilig leven. Kampen : Kok

VELEMA, W.H. 1996. Door het Woord bewogen. Leiden : Groen \& Zoon.

WURTH, G.B. 1934. De Christelijke vrijheid. Kampen : Kok.

WURTH, G.B. 1947. De Christelijke zedeleer en haar bestrijders. Den Haag : Voorhoeve.

WURTH, G.B. 1951. Het Christelijk leven in de maatschappij. Kampen : Kok.

WURTH, G.B. 1957. Het Christelijk leven: Grondlijnen der ethiek. Kampen : Kok. 
